\title{
TIME-LAPSE MICRO-TOMOGRAPHY ANALYSIS OF THE DEFORMATION RESPONSE OF A GELLAN-GUM-BASED SCAFFOLD
}

\author{
MIKROTOMOGRAFSKA ANALIZA S ČASOVNIM ZAMIKOM \\ ODZIVA DEFORMACIJE OGRODJA IZ GELANSKEGA GUMIJA
}

\author{
Daniel Kytýřr ${ }^{1,2}$, Nela Fenclová1,2, Petr Zlámal ${ }^{1,2}$, Ivana Kumpová2 ${ }^{1,}$ Tomáš Fíla ${ }^{1,2}$, \\ Petr Koudelka ${ }^{1,2}$, Ana Gantar ${ }^{3,4}$, Sasa Novak ${ }^{3,4}$ \\ ${ }^{1}$ Czech Technical University, Faculty of Transportation Sciences, Department of Mechanics and Materials, Konviktská 20, \\ 11000 Prague 1, Czech Republic \\ 2Institute of Theoretical and Applied Mechanics, v.v.i., Academy of Sciences of the Czech Republic, Prosecká 76, 19000 Prague 9, \\ Czech Republic \\ ${ }^{3}$ Jožef Stefan Institute, Department for Nanostructured Materials, Jamova cesta 39, 1000 Ljubljana, Slovenia \\ 4Jožef Stefan International Postgraduate School, Jamova cesta 39, 1000 Ljubljana, Slovenia \\ kytyr@fd.cvut.cz
}

Prejem rokopisa - received: 2015-07-27; sprejem za objavo - accepted for publication: 2016-05-20

\author{
doi:10.17222/mit.2015.237
}

\begin{abstract}
The presented work is aimed at a demonstration of modern radiological methods for an investigation of the deformation behaviour of bone scaffolds. Bone scaffold is an artificial structure used for the repairs of trabecular bones damaged by injuries or degenerative diseases. In bone-tissue engineering a proper description of its deformation behaviour is one of the most important characteristics for an assessment of the biocompatibility and bone-integration characteristics of the proposed structure intended to be used as a bone scaffold. According to recent studies bioactive-glass-reinforced gellan-gum (GG-BAG) is a promising material for bone-scaffold production. However, its low specific stiffness and simultaneous low attenuation to X-rays makes both the mechanical and imaging parts of the deformation experiments difficult. As a result a state-of-the-art experimental setup composed of high-precision micro-loading apparatus designed for the X-ray observation of deformation processes and an advanced radiographical device is required for such experiments. Furthermore, the radiographical device has to utilize highly sensitive detectors and corresponding radiation sources with appropriate beam characteristics that provide a high signal-to-noise ratio $(S N R)$ during all the measurements. High-resolution time-lapse micro-focus X-ray computed tomography (micro CT) under loading in three different imaging modes was performed to obtain a precise structural and mechanical description of the observed deforming GG-BAG scaffolds. The digital volumetric correlation (DVC) method was applied on reconstructed data from micro CT measurements to evaluate not only the effective mechanical characteristics but also to enable a detailed inspection of the specimens' internal structure, particularly the deformation modes of the individual struts and joints. The calculated volumetric strain fields demonstrate the suitability of such experimental methodology and devices for the assessment of both the microscopic and macroscopic characteristics of the investigated complex GG-BAG microarchitectures. Keywords: bone scaffold, gellan gum, time-lapse micro CT, digital volume correlation
\end{abstract}

Predstavljeno delo je namenjeno prikazu sodobnih radioloških metod za preiskave obnašanja deformacije kostno-regenerativnih celičnih ogrodij. Takšno celično ogrodje je tridimenzionalna umetna struktura, ki se uporablja za regeneracijo trabekularne kosti ob poškodbah ali pri degenerativnih boleznih. Pravilen opis obnašanja ogrodja ob deformaciji je eden od pomembnejših faktorjev za določitev biokompatibilnosti ogrodja, in kako se bo to ogrodje vključilo v tkivo, v katerega je vstavljeno. Glede na nedavne študije, je kompozit bioaktivno steklo - gelanski gumi (GG-BAG), obetaven material za pripravo kostno-regenerativnih celičnih ogrodij. Zaradi nizke specifične togosti materiala in slabljenja rentgenskih žarkov, je oteženo zaznavanje deformacije, tako mehansko kot tudi z rentgenskimi žarki. Zaradi zahtevnosti sistema je za tako preizkušanje potrebna posebna naprava, sestavljena iz mikrotlačne naprave $\mathrm{z}$ visoko natančnostjo, ki je načrtovana za opazovanje deformacije med slikanjem z rentgenskimi žarki, ter napredne radiografske naprave. V sklopu sistema so potrebni tudi detektorji visoke občutljivosti in ustrezen vir žarčenja, z ustrezno značilnostjo snopa, ki zagotavljajo visoko razmerje med signalom in šumom (angl. SNR) med merjenji. Ob kompresiji vzorca je bila izvedena visokoločljivostna mikrofokusna rentgenska računalniška tomografija (angl. micro CT) s časovnim zamikom, $\mathrm{v}$ treh različnih načinih slikanja, za pridobitev natančnega konstrukcijskga in mehanskga opisa opaženih deformiracij GG-BAG kostno-regnerativnih celičnih ogrodij. Digitalna volumetrična korelacijska (DVK) metoda je bila uporabljena pri rekonstruiranih podatkih meritev z mikro-CT, za ovrednotenje efektivnih mehanskih karakteristik in tudi za podroben pregled notranje strukture vzorcev ob obremenitvi, zlasti načinov deformacije posameznih opornikov in spojev znotraj celičnega ogrodja. Volumetrično izračunana območja obremenitev prikazujejo ustreznost takšne eksperimentalne metodologije in naprave za določevanje, tako mikroskopskih kot makroskopskih, lastnosti kompleksne mikroarhitekture preiskovanega GG-BAG kompozita.

Ključne besede: celično ogrodje, gelanska guma, mikro-CT s časovnim zamikom, digitalna volumska korelacija 
D. KYTÝŘ et al.: TIME-LAPSE MICRO-TOMOGRAPHY ANALYSIS OF THE DEFORMATION RESPONSE ...

\section{INTRODUCTION}

To successfully develop an artificial bone scaffold various fundamental requirements have to be fulfilled: i) the provision of normal cellular activity without potential toxicity, ii) the minimization of potential stress shielding effects, iii) the reliable long-term supply of organic/anorganic nutrients and oxygen and iv) the controlled progressive degradation and resorption of the scaffold during healing. ${ }^{1}$ Apparently, these requirements also closely comply with the general goals of modern bone-tissue engineering. However, in contrast to established materials for bone-tissue engineering (particularly HAP) the usage of GG-BAG for scaffold production may significantly reduce the potential for complications due to various influences, including donor site morbidity, limited availability, immune rejection and pathogen transfer. ${ }^{2}$ Here, the successful application of a GG-BAG-based scaffold allows healing of the bone, even in the case of its partial amputation, supports natural formation of bone tissue according to stress fields and thus full restoration of the bone's primary function the provision of mechanical support.

High-resolution time-lapse micro-focus X-ray computed tomography (micro CT) is currently the only feasible method for an investigation of volumetric deformation processes of micro-structural materials and specimens during loading. ${ }^{3}$ Moreover, due to the very complex, spontaneously synthesized, stochastic scaffold microarchitecture description of its mechanical properties based on the overall characteristics appears to be insufficient. In the presented work a custom-designed experimental setup allowing the performance of mechanical testing during radiographical imaging is employed to evaluate detailed volumetric strain fields in the deforming scaffolds' microstructure using digital volumetric correlation (DVC). ${ }^{4}$

\section{MATERIALS AND METHODS}

\subsection{Bioactive-glass-reinforced gellan-gum scaffolds}

The recently proposed bioactive-glass-reinforced gellan-gum (GG-BAG), which is a promising material for bone scaffold fabrication, was used in this study. ${ }^{5}$

Gellan-gum (GG) is a microbial extracted polysaccaride used in the food and pharmaceutical industries. ${ }^{6,7}$ GG is composed of repeating units consisting of two D-glucose and one of each L-rhamnose and D-glucuronic acid. ${ }^{8}$ Its main advantage is in an ability to form highly porous $3 \mathrm{D}$ structures when properly cross-linked and fabricated. ${ }^{9}$ In the field of bone regeneration the GG is biocompatible and biodegradable but it doesn't have sufficient mechanical properties to enable successful bone regeneration and it does not promote bone formation. Therefore, GG has to be reinforced by bioactive glass particles (BAG).

BAG is a nano-particulate amorphous material with a chemical composition of $70 \mathrm{n} / \mathrm{n} \% \mathrm{SiO}_{2}$ and $30 \mathrm{n} / \mathrm{n} \%$
$\mathrm{CaO}$ and it is prepared by a modified sol-gel method. ${ }^{10}$ BAG is a bioactive material and upon biodegradation there are no toxic products left behind. Therefore, BAG particles are very interesting for bone-regeneration applications.

During the production process gellan gum was dissolved in ultra-pure water by heating the solution for $30{ }^{\circ} \mathrm{C}$ min at $90{ }^{\circ} \mathrm{C}$. To the hot $\mathrm{GG}$ solution a dispersion of $\mathrm{BAG}$ was admixed and $0.18 \mathrm{w} / \mathrm{w} \% \mathrm{CaCl}_{2}$ was added. Kept at high temperatures this mixture was then poured into the required mould and let there to spontaneously jellify. The weight ratio between GG and BAG was 1:1 and the final concentration of $\mathrm{CaCl}_{2}$ was $0.03 \mathrm{w} / \mathrm{w} \%$ in all samples. Such samples were frozen $12 \mathrm{~h}$ at $-80{ }^{\circ} \mathrm{C}$ and freeze-dried for $3 \mathrm{~d}$ in Lio 5 freeze dryer Kambič. ${ }^{5}$

Table 1: Dimensions and weights of the samples subjected to mechanical testing

Tabela 1: Dimenzije in masa vzorcev za mehanske preizkuse

\begin{tabular}{|c|c|c|c|}
\hline & Specimen 1 & Specimen 2 & Specimen 3 \\
\hline Weight mg & 11.2 & 10.4 & 24.7 \\
\hline Width mm & $5.95-6.20$ & $5.89-6.28$ & $5.79-6.24$ \\
\hline Height mm & $6.04-6.08$ & $6.54-6.62$ & $7.93-8.21$ \\
\hline BAG & no & no & yes \\
\hline $\begin{array}{c}\text { CT measure- } \\
\text { ment }\end{array}$ & $\begin{array}{c}\text { Photon count- } \\
\text { ing detector, } \\
\text { continual } \\
\text { loading }\end{array}$ & $\begin{array}{c}\text { Photon count- } \\
\text { ing detector, } \\
\text { discrete loading } \\
\text { steps }\end{array}$ & $\begin{array}{c}\text { Flat panel } \\
\text { detector, dis- } \\
\text { crete loading } \\
\text { steps }\end{array}$ \\
\hline
\end{tabular}
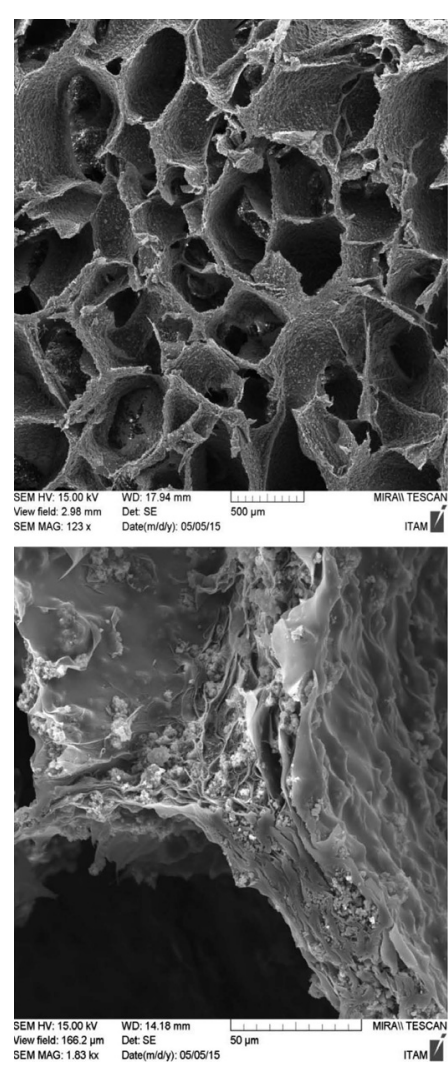

Figure 1: SEM micrograph of the scaffold obtained by scanning electron microscopy

Slika 1: SEM-posnetek celičnega ogrodja 
Dimensions and weights of the three scaffolds manufactured from GG are presented in Table 1, and details of their microstructure is shown in Figure $\mathbf{1}$.

\subsection{Mechanical testing}

Compression tests of the GG-BAG samples were performed using a custom-designed uni-axial loading device. The device was designed to be suitable for mechanical testing of materials during continuous observation using $\mathrm{X}$-rays including computed micro-tomography. Therefore, the main frame of the device is made of transparent polymethyl methacrylate tube with a 5.0 $\mathrm{mm}$ wall thickness and negligible X-ray attenuation. The loading mechanism consists of a stepper motor, flexible coupling, planetary gear unit P42-25 (Transtecno, Italy) and translation stage with micro-metric screw 7T173-20 (Standa, Lithuania). Such a mechanism is able to stress the specimen with a loading speed of $0.1-20 \mu \mathrm{m} \mathrm{s}^{-1}$ with an experimentally measured movement accuracy of better than $5 \mu \mathrm{m}$. The loading procedure is controlled by a GNU/Linux real-time operational system. In the case of scaffold measurements the device was equipped with a high-accuracy load cell and a 50-N load capacity HBM U9C (HBM, Germany).

\subsection{Radiographical imaging}

$\mathrm{X}$-ray imaging of the compression tests was carried out using a modular X-ray setup with cone-beam tomography arrangement. As the GG-BAG material has very a low attenuation of $\mathrm{X}$-rays three different scanning approaches were employed to find the best settings for the scaffold imaging. Conventional scanning at discrete loading steps using a flat panel detector was selected as a first option. Scanning using a photon counting detector in discrete loading steps was selected as a second option and a continuous fast tomography measurement (without loading steps) using a photon counting detector as a third option. In all cases the X-ray beam was generated by micro-focus X-ray tube with reflection target (XWT-
240-SE, X-Ray Worx, Germany) operated at $50 \mathrm{kV}$, a $500 \mu \mathrm{A}$ target current and a focal spot size of $5 \mu \mathrm{m}$. $\mathrm{X}$-ray images of sample 3 were taken using a large area flat panel scintillating detector (Perkin Elmer XRD 1622 AP, USA) with an effective resolution of $2048 \times 2048$ px. The setup geometry was adjusted to $1230 \mathrm{~mm}$ focus-detector distance and $123 \mathrm{~mm}$ focus-object distance. Therefore, planar X-ray images resulted in $10 \times$ magnification and a $20 \mu \mathrm{m}$ pixel size. One highly detailed tomography of the undeformed specimen (1200 projections) and three regular tomography scans (800 projections) at three different loading steps were taken. For scanning of another two samples (sample 1 and sample 2) a modular photon-counting detector consisting of $2 \times 2$ TimePIX chips with fast read-out (the ModuPIX detector) and an effective resolution of $1024 \times 1024$ px was employed. As a photon-counting detector and fast tomography requires an X-ray beam with high intensity the focus-detector distance was reduced to $175.5 \mathrm{~mm}$ and the focus-object distance was reduced to $95 \mathrm{~mm}$. Thus, planar X-ray images in the case of imaging using photon counting detector resulted in $1.84 \times$ magnification and $30 \mu \mathrm{m}$ pixel size. Sample 2 was scanned in 6 discrete loading steps. A total of 600 projections were acquired in each tomography measurement. Sample 1 was loaded continuously with $0.1 \mu \mathrm{m} . \mathrm{s}^{-1}$ loading speed and several tomography scans were taken with no time separation. In this case 400 projections were acquired in each tomography and one CT scan lasted approx. $4.5 \mathrm{~min}$. The specimen was compressed by approximately $30 \mu \mathrm{m}$ displacement during one CT scan (approx. 1 pixel in X-ray images). Linearization of the attenuation range (beam hardening correction) was applied to all the data to reduce the noise and improve the contrast in individual projections. ${ }^{11}$ Due to high porosity of the samples and the small thickness of the structural elements (approximately $30 \mu \mathrm{m}$ ), the cone-beam reconstruction algorithm ${ }^{12}$ was used to eliminate the distortion of the reconstructed data caused by the divergent nature of the X-ray beam.

The setup for radiographical imaging is shown in Figure 2.

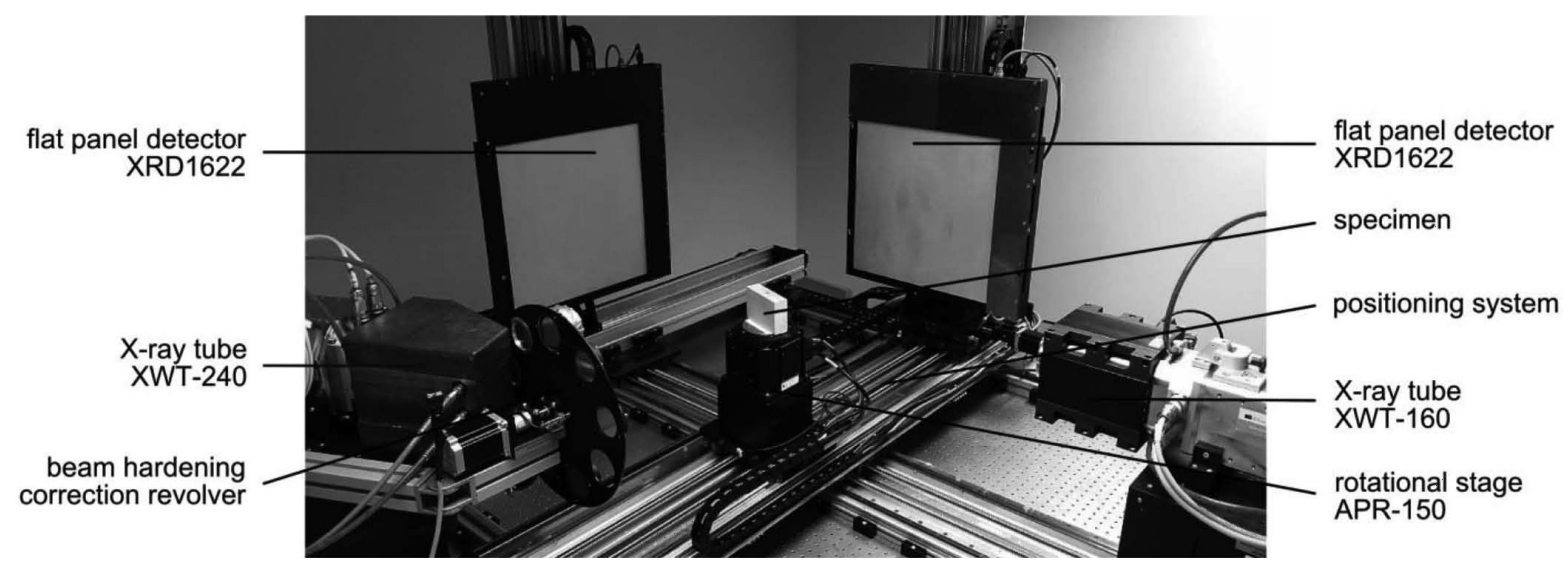

Figure 2: Microtomographical setup arrangement

Slika 2: Mikrotomografski sestav 
D. KYTÝŘ et al.: TIME-LAPSE MICRO-TOMOGRAPHY ANALYSIS OF THE DEFORMATION RESPONSE ...

\subsection{Deformation mapping using digital volume corre- lation}

The digital volumetric correlation (DVC) technique is a suitable tool for an evaluation of displacements and strains within the entire volume of the samples. The method makes it possible to track the changes in a sequence of volumetric images and to calculate the displacement of nodes representing the microstructure of the investigated samples. DVC uses the maximisation approach to find the correlation coefficient for the best fit between sub-image data defined around control points established in the reference image data. The correlation coefficient is evaluated by examining the pixel intensity of the image subsets in the corresponding image data and then the deformation mapping function is extracted. To maximise the correlation coefficient a nonlinear optimisation technique and an iterative approach were used. Coefficients of the linear affine transformation between the undeformed and deformed states can be used to establish the components of the displacement vector and the components of the gradient tensor. Then, using the deformation gradient tensor $F$ it is possible to calculate the Green-Lagrangian strain tensor as Equation (1):

$$
E=F^{T} F-I
$$

The calculation of the inner deformation of the samples in all the loading states was performed using the custom DVC algorithm implemented in Matlab. Due to the computational complexity only two mutually perpendicular vertical planes passing through the centre of each sample were used for the displacement calculations. It was assumed that the displacement of the nodes in these planes sufficiently describes the deformation behaviour of the whole sample. The initial position of the tracked nodes corresponding to these planes was selected on the basis of detailed voxel model of each sample in the intact state.

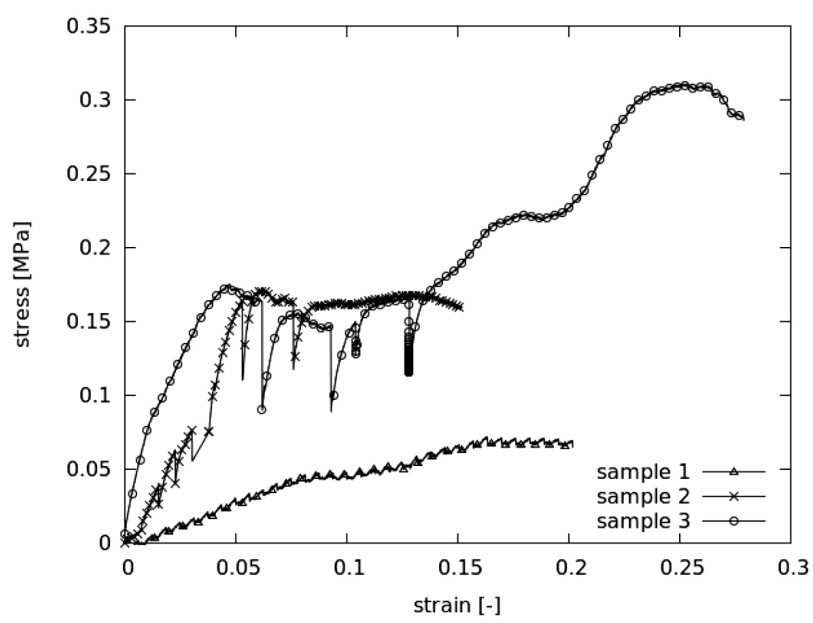

Figure 3: Stress-strain curves of the tested GG-BAG scaffolds

Slika 3: Krivulje obremenitev-deformacija preizkušenih GG-BAG celičnih ogrodij

\section{RESULTS AND DISCUSSION}

Three samples were subjected to compressive loading using a uni-axial loading device and the deformation behaviour of the inner structure was captured using $\mathrm{X}$-ray imaging technique. Samples 2 and 3 were loaded in several successive phases (between the phases the tomography of sample was performed) while sample 1 was loaded continuously with a $0.1 \mu \mathrm{m} \mathrm{s}^{-1}$ loading speed. Stress-strain curves of these loading tests are shown in Figure 3. In the case of samples 2 and 3 it is clearly apparent that considerable relaxation of the samples (sudden decrease in stress value) occurred during the tomographic imaging. On the other hand, the stressstrain curve of sample 1 is not affected by the relaxation process because the tomographic imaging was performed during the loading process and the load applied to the sample was continuously incremented without interruption. The small repetitive decreases of the stress value visible on the stress-strain curve in this case are not a relaxation of the sample but were caused by the technical limitations of the experimental setup. As the loading device is equipped with supply cables the rotation stage with the loading device had to be returned to the initial position and the vibration of the rotation table during the homing sequence caused the micro-movement of the sample.

As expected the stiffness of sample 3 was higher than in case of non-reinforced samples 1 and 2. A mutual comparison of the response of non-reinforced samples 1 and 2 shows large difference of stiffness presumably

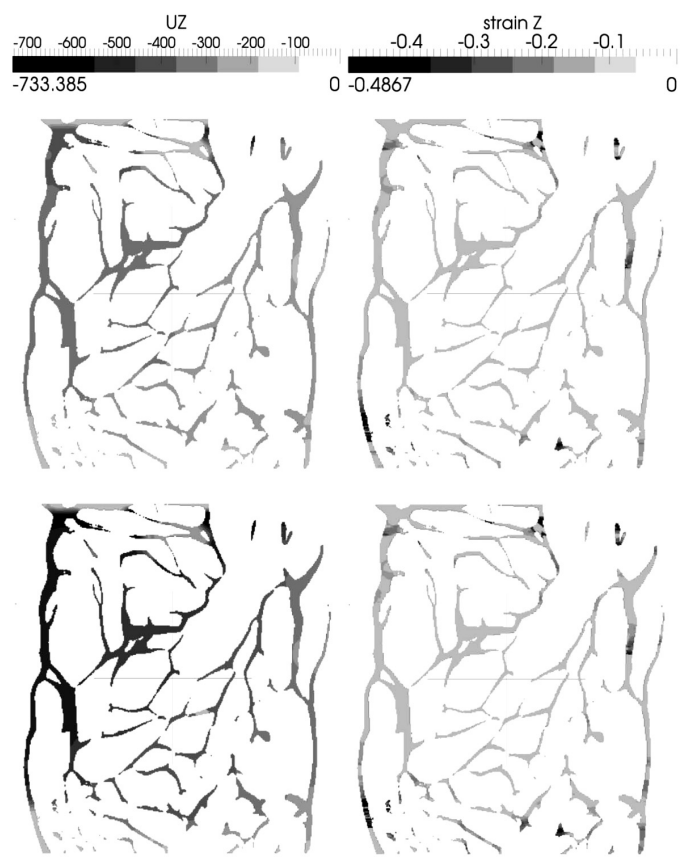

Figure 4: Displacement in z-direction $(\mu \mathrm{m})$ and Green-Lagrangian strain of the sample $3 ; 8 \%$ overall deformation; $12 \%$ overall deformation

Slika 4: Premik v z-smeri $(\mu \mathrm{m})$ in Green-Lagrangianova obremenitev vzorca $3 ; 8 \%$ celotna deformacija, $12 \%$ celotna deformacija 
D. KYTÝ $̌$ et al.: TIME-LAPSE MICRO-TOMOGRAPHY ANALYSIS OF THE DEFORMATION RESPONSE ...

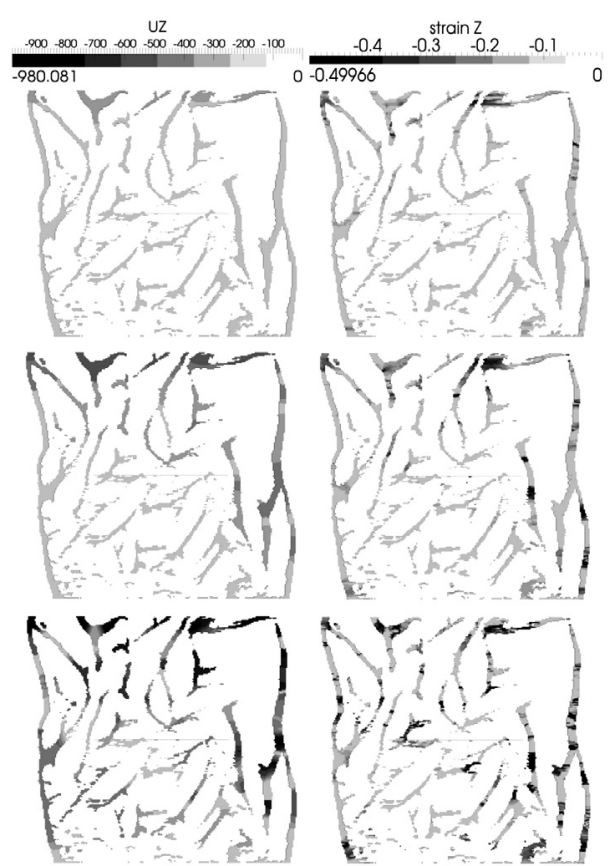

Figure 5: Displacement in z-direction $(\mu \mathrm{m})$ and Green-Lagrangian strain of the sample 2: $3 \%$ overall deformation (top); $5 \%$ overall deformation; $7 \%$ overall deformation

Slika 5: Premik v z-smeri $(\mu \mathrm{m})$ in Green-Lagrangianova obremenitev vzorca 2; $3 \%$ celotna deformacija, $5 \%$ celotna deformacija, $7 \%$ celotne deformacije

caused by the different nature of the spontaneously synthesized inner structure. Because of the complex inner structure of the scaffolds the overall (effective) strain assessed from the movement of the loading platens is not reliable parameter for characterising the deformation behaviour of such a material. Therefore, an advanced strain calculation based on the DVC technique was used in the study.

The DVC algorithm is extensively time-consuming and its computational cost linearly increases with the number of calculated deformation states. For this reason, only the displacement of nodes belonging to two mutually perpendicular vertical planes located in the centre of each sample were used (for sample 3 only one plane was used). These planes (YZ and XZ orientation) included: 14,720 nodes and 19,790 nodes for sample 1; 24,452 nodes and 23,076 nodes for sample 2; 46,728 nodes for sample 3 . A larger number of nodes in the case of sample 3 relates to higher resolution of the flat panel detector. During the parallel DVC calculation (4 threads of Intel i7-3820 CPU) the displacement vector of each node in the selected plane through all the loading states was determined. Green-Lagrangian strain of every voxel was evaluated on the basis of displacement vectors of its corresponding nodes. Fields of the vertical displacement and the evaluated strain for one plane of each sample in selected deformation states mapped on the structure of the intact state are shown in Figures 4 to 6. The obtained deformation and strain fields show that the DVC technique can be successfully used for a determination of

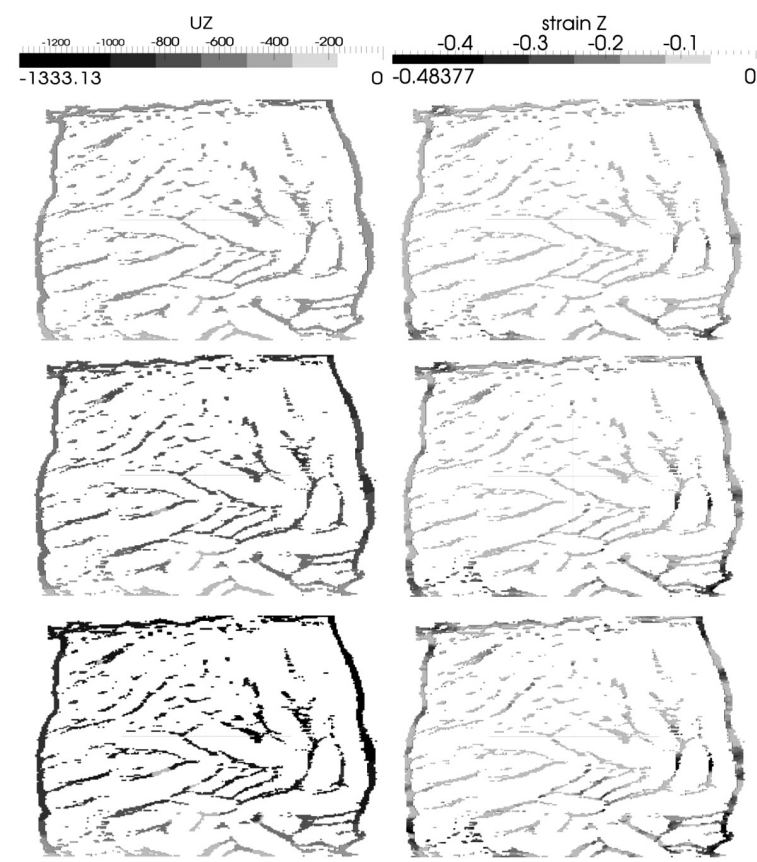

Figure 6: Displacement in z-direction $(\mu \mathrm{m})$ and Green-Lagrangian strain of the sample 1: $6 \%$ overall deformation; $13 \%$ overall deformation; $20 \%$ overall deformation

Slika 6: Premik v z-smeri $(\mu \mathrm{m})$ in Green-Lagrangianova obremenitev vzorca 1; $6 \%$ celotna deformacija, $13 \%$ celotna deformacija, $20 \%$ celotne deformacije

such complex deformation processes. As can be seen from the results the deformation of the samples was not limited only to uni-axial compression, as anticipated, but apparent bending of the samples caused by their complex inner structure, improper boundary conditions and sample geometry was present. Despite our best efforts, it was not possible to manufacture the samples with plan-parallel top and bottom faces. The evaluation of the elastic parts of the resulting stress-strain curves also showed the reason for the lower stiffness of the sample 1 when compared to the sample 2. As can be seen in Figure 6 the struts of the inner structure of the sample 1 are oriented perpendicularly to the applied load while the struts of the inner structure of sample 2 (Figure 5) are mainly oriented in the direction of loading.

\section{CONCLUSIONS}

In this work the demonstration of modern radiological and computational methods for the investigation of the deformation behaviour of artificial bone scaffolds was shown.

Three samples were loaded using a custom uni-axial compression device and tomographically scanned in three different loading scenarios: i) flat panel scintillating detector with incremental loading steps, ii) fast photon-counting detector with incremental loading steps and iii) fast photon-counting detector with continuous loading. In the case of incrementally applied loading divided into individual steps the relatively large relaxa- 


\section{KYTÝŘ et al.: TIME-LAPSE MICRO-TOMOGRAPHY ANALYSIS OF THE DEFORMATION RESPONSE ...}

tion of the sample was observed during the tomography scanning. This undesirable relaxation process was eliminated in a scenario with continuous loading, which was made possible by the advantageous characteristics of the single photon-counting detectors, the fast readout speed and very high signal-to-noise ratio. Although the number of tomographic projections during continuous loading was halved compared to other scenarios the reconstructed tomographic data still had sufficient quality for a reliable DVC calculation. This fact clearly demonstrates the suitability of the photon-counting detector for the imaging of samples with a low attenuation of X-rays. Future work will be focused on improvements to the parameters of the compression test with continuously performing tomography using a fast photon-counting detector to obtain precise data for calculation of the mechanical characteristic of scaffold as well as speeding up the measurement.

\section{Acknowledgements}

The research was supported by Grant Agency of the Czech Technical University in Prague (grant no. SGS15/225/OHK2/3T/16) and by institutional support RVO: 68378297. The Slovenian Research Agency is acknowledged for its financial support of the PhD study of the co-author, Ms. Ana Gantar (PR-03770).

\section{REFERENCES}

${ }^{1}$ H. L. M. Bao, E. Y. Teo, M. S. K. Chong, Y. Liu, M. Choolani, J. K. Y. Chan, Advances in Bone Tissue Engineering, Regenerative Medicine and Tissue Engineering, Rijeka, InTech, 2013, doi:10.5772/ $55916 \mathrm{D}$

${ }^{2}$ A. R. Amini, C. T. Laurencin, S. P. Nukavarapu, Bone Tissue Engineering: Recent Advances and Challenges, Critical reviews in biomedical engineering, 40 (2012) 5, 363-408, doi:10.1615/CritRevBiomedEng.v40.i5.10

${ }^{3}$ O. Jirousek, P. Zlamal, D. Kytyr, M. Kroupa, Strain analysis of trabecular bone using time-resolved X-ray microtomography, Nuclear Instruments and Methods in Physics Research Section A: Accelerators, Spectrometers, Detectors and Associated Equipment, 633 (2011) 1, 148-151, doi:10.1016/j.nima.2010.06.151

${ }^{4}$ B. K. Bay, Methods and applications of digital volume correlation, The Journal of Strain Analysis for Engineering Design, (2008), 43, 745-760, doi:10.1243/03093247JSA436

${ }^{5}$ A. Gantar, L. P. da Silva, J. M. Oliveira, A. P. Marques, V. M. Correlo, S. Novak, R. L. Reis, Nanoparticulate bioactive-glass-reinforced gellan-gum hydrogels for bone-tissue engineering, Materials Science and Engineering C, 43 (2014), 27-36, doi:10.1016/j.msec. 2014.06.045

${ }^{6}$ D. Hoikhman, Y. Sela, Gellan gum based oral controlled release dosage forms- anovel platform technology for gastric retention. Google Patents, 2006

${ }^{7}$ D. E. Pszczola, Gellan gum wins IFT's food technology industrial achievement award, Food Technology 1993, 47, 94-6

${ }^{8}$ P.-E. Jansson, B. Lindberg, P. A. Sandford, Structural studies of gellan gum, an extracellular polysaccharide elaborated by Pseudomonas elodea. Carbohydr Res 1983, 124, 135-9

${ }^{9}$ J. T. Oliveira, L. Martins, R. Picciochi, P. B. Malafaya, R. A. Sousa, N. M. Neves, et al. Gellan gum: a new biomaterial for cartilage tissue engineering applications. Journal of biomedical materials research Part A, 2010, 93, 852-63

${ }^{10}$ N. Drnovsek, S. Novak, U. Dragin, M. Ceh, M. Gorensek, M. Gradisar, Bioactive glass enhances bone ingrowth into the porous titanium coating on orthopaedic implants. Int Orthop 2012, 36, 1739-45, doi:10.1007/s00264-012-1520-y

${ }^{11}$ D. Vavrik, J. Jakubek, Radiogram enhancement and linearization using the beam hardening correction method, Nuclear Instruments and Methods in Physics Research Section A: Accelerators, Spectrometers, Detectors and Associated Equipment, 607 (2009) 1, 212-214, doi:10.1016/j.nima.2009.03.156

${ }^{12}$ L. A. Feldkamp, L. C. Davis, J. W. Kress, Practical cone-beam algorithm, Journal of the Optical Society of America A, 1 (1984) 6, $612-619$ 